\title{
New Ceratocystis species infecting coffee, cacao, citrus and native trees in Colombia
}

\author{
M. Van Wyk • B. D. Wingfield • M. Marin • \\ M. J. Wingfield
}

Received: 21 October 2009 / Accepted: 15 November 2009

(C) Kevin D. Hyde 2010

\begin{abstract}
Ceratocystis fimbriata sensu lato includes a large number of plant and especially tree pathogens. In Colombia, isolates of this fungus cause a serious cankerstain disease on coffee as well as other fruit trees. Large collections of these isolates have been shown to occur in two distinct phylogenetic lineages based on ITS sequence comparisons. The aim of this study was to compare representatives of these two groups of isolates from coffee, citrus, cacao and native trees in Colombia, based on morphology and DNA-sequences for three gene regions. Host-specificity of the fungus was also considered. Representatives of the two groups of isolates were morphologically distinct and could be distinguished based on DNA sequence comparisons. They are also distinct from other species in the C. fimbriata sensu lato species complex and the sweet potato pathogen $C$. fimbriata sensu stricto and are provided with the names $C$. colombiana sp. nov and $C$. papillata sp. nov. There was no evidence for host-specificity amongst isolates of these two fungi that collectively represent a serious threat to coffee production in Colombia.
\end{abstract}

Keywords Ophiostomatoid fungi $\cdot$ Phylogenetic relationships $\cdot$ Species concepts $\cdot$ Tree diseases

M. Van Wyk $(\bowtie) \cdot$ B. D. Wingfield $\cdot$ M. J. Wingfield

Department of Genetics,

Forestry and Agricultural Biotechnology Institute (FABI),

University of Pretoria,

Pretoria 0002, South Africa

e-mail: marelize.vanwyk@fabi.up.ac.za

M. Marin

National University of Colombia,

Medellin A.A. 3840, Colombia

\section{Introduction}

Colombia is the world's largest producer of coffee (Coffea arabica L.) and depends on this product for foreign exchange. It is consequently worrying that this crop is seriously affected by a canker-stain disease caused by Ceratocystis fimbriata Ellis \& Halst. sensu lato (s.l.). The first record of coffee canker disease caused by this fungus, was from the island of Java (Indonesia) in 1900 (Pontis 1951) and it was first recorded in Colombia in 1932 (Zimmerman 1900; Castaño 1951).

Canker stain disease caused by $C$. fimbriata s.l. in Colombia is found on a wide range of hosts other than coffee. These include citrus (Citrus reticulata Blanco, Citrus sinensis (L.) Osbeck and Citrus limon (L.) Burm. f.) barinas nut (Caryodendron orinocense H. Karst.), mango (Mangifera indica L.), rubber (Hevea brasiliensis (Willd.) Müll. Arg.) cacao (Theobroma cacao L.) and several native forest trees including Schizolobium parahybum (Vell.) S.F. Blake and Annona muricata L. (Castaño 1951; Webster and Butler 1967; Kile 1993; Mourichon 1994; Pardo-Cardona 1995; Marin et al. 2003). Coffee is frequently cultivated in close proximity to citrus and native trees and it is likely that inoculum of the pathogen is readily exchanged between these plants.

Ceratocystis fimbriata s.l. requires wounds for infection and these are created during pruning and other cultivation practices (Pontis 1951; Marin et al. 2003). In some cases, the source of infection is chlamydospore-infested soil (Rossetto and Ribeiro 1990; Marin et al. 2003; Marin 2004). Ceratocystis fimbriata was first described based on isolates of the fungus causing black rot of sweet potato in the United States of America (Halsted 1890). Subsequently, the fungus was associated with diseases of a large number of different plant species in many parts of the world. While 